\title{
PETROLOGY AND CHEMISTRY OF BASIC ROCKS FROM THE NORTH- CENTRAL REGION OF THE MANTIQUEIRA PROVINCE, BRAZIL
}

J.M.Correia Neves ${ }^{1,2}$

H.A.Horn ${ }^{1,2}$

Between the Coastal Belt and the São Francisco Craton basic melts intruded the basement (Fig. 1) related to different tectonic and thermo-tectonic events over geologic time. Available petrological, chemical and radiometric data on the basic rocks from the study area may be divided into the following distinct groups:

1. Basic rocks of alkaline affinity associated with ultrabasic rocks of the Espinhaço Supergroup. These rocks are characterized by high values of $\mathrm{TiO}_{2}$ and $\mathrm{Na}_{2} \mathrm{O}$ and low values of $\mathrm{K}_{2} \mathrm{O}$. Metamorphism is common and foliation is parallel to the regional structural trend.

2. Basic rocks of the southern and southeastern parts of the area (Quadrilatero Ferrffero). These highly metamorphosed rocks occur in Archean greenstone belts; their foliation is parallel to the regional trend.

3. Alkaline basic rocks (gabbros and basalts) with high contents of $\mathrm{Na}_{2} \mathrm{O}, \mathrm{K}_{2} \mathrm{O}$, $\mathrm{TiO}_{2}, \mathrm{P}_{2} \mathrm{O}_{5}$ and $\mathrm{BaO}$, exhibiting alkaline to calcalkaline differentiation trends. They are localized in the Coastal Mobile Belt and in the outcropping parts of the Parafba do Sul Complex (HORN, 1986; WIEDEMANN et al., 1986).

4. Basic rocks in the undifferentiated basement between the Coastal Mobile Belt and the Espinhaço range (CORREIA NEVES \& HORN, 1988), can be subdivided in to at least three subgroups:

a. Tholeitic basic rocks with foliation and metasomatic alteration (oldest group).

\footnotetext{
${ }^{1}$ Centro de Pesquisa Prof. Manoel Teixeira da Costa, Instituto de Geociências, Universidade Federal de Minas Gerais, Caixa Postal 2608, Belo Horizonte, MG, Brazil.

${ }^{2}$ The CNPq provided financial support.
} 


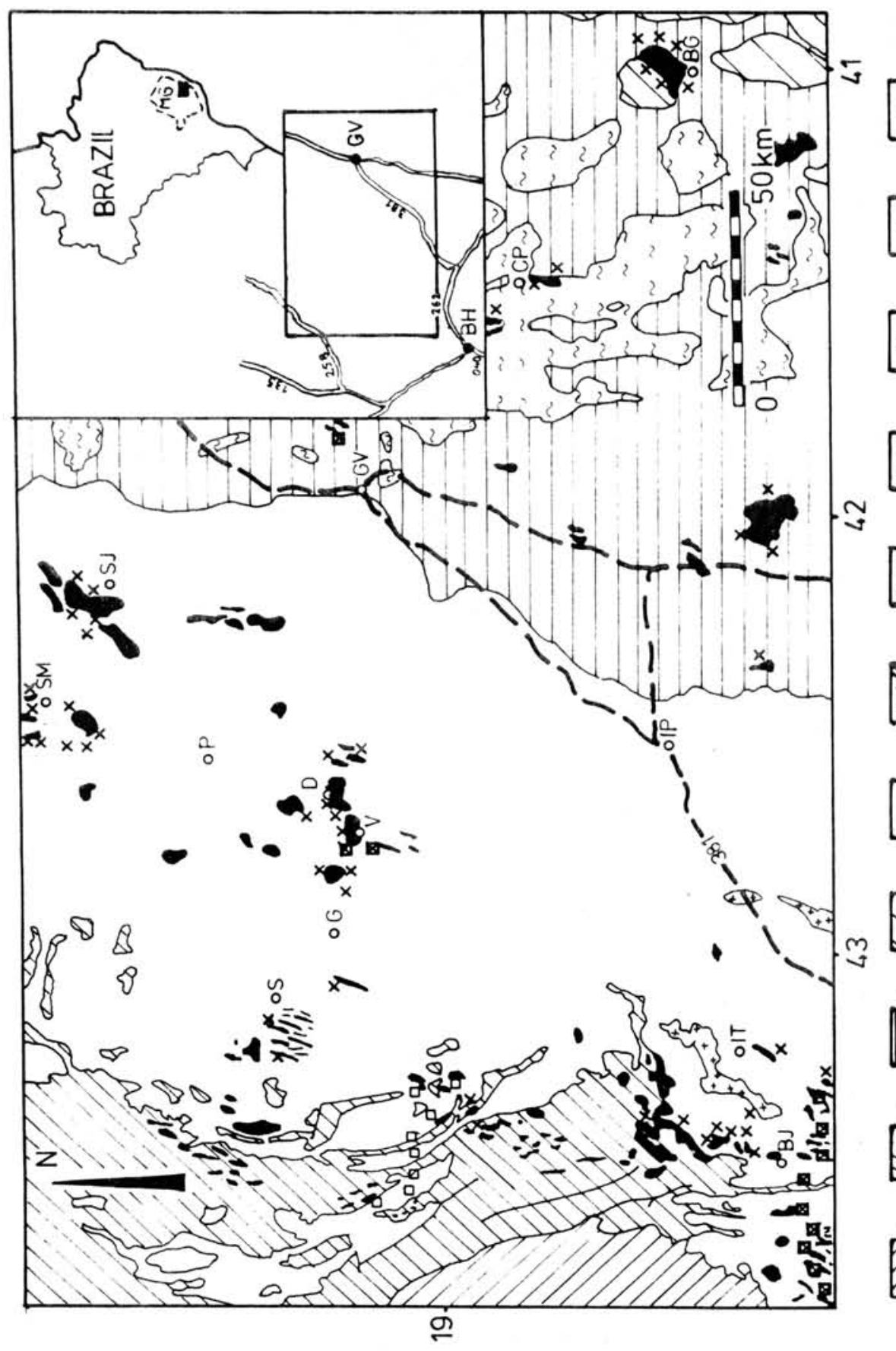

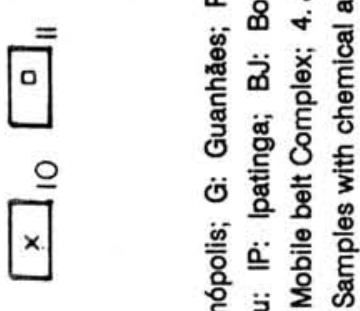

ब

क $x$ ल ॠ

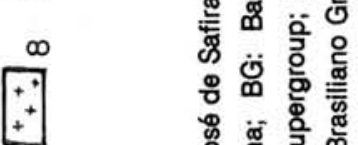

\% ฒ

ᄀ

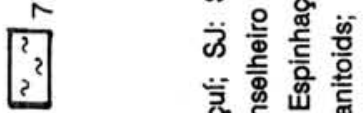

苛

6 के ㅎํㅇ 홍

1. 幂

n के के

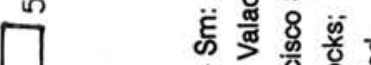

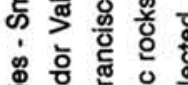

+ $\quad$ क्ष

寸

8े 웧

m1

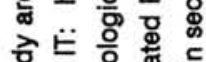

N

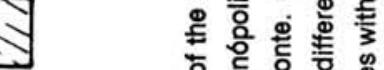

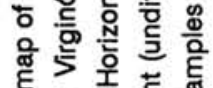

ए

듷

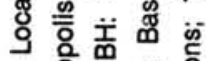

$\therefore$ 든 훙 응

닉 文 앵

面 旅 
b. Tholeiitic basic rocks with flux foliation and low-grade metasomatism.

c. Coarser-grained basic rocks, with or without weak tectonic influence and metasomatism. They have high contents of $\mathrm{TiO}_{2}$ and $\mathrm{BaO}$ and are normally calcalkaline with a slightly tholeiitic affinity, probably associated with the final phase of the Brasiliano event.

5. Tholeiitic (sensu lato) basic rocks, related to the evolution of the Atlantic Ocean in the Cretaceous. They are characterized by high iron content and low barium, alkali and titanium contents.

The chemical evolution of these groups of intrusive rocks shows clearly the modifications of the mantle during geologic time. Table 1 lists the main composition of the investigated dikes and stocks.

The $\mathrm{SiO}_{2}$-Alkali-Harker-diagram (Fig. 2) shows the relation of the studied samples with the chemical mean-values of basic rocks from the Espinhaço range (BIONDI et al., 1978), the Coastal region (WIEDEMANN et al., 1984; HORN, 1986) and two groups of basic rocks from the Guanhães area (OLIVEIRA et al., 1984; our unpublished data).

Table 1 - Chemical analyses of the rock samples of Figure 1.

\begin{tabular}{|c|c|c|c|c|c|c|c|c|c|c|c|c|c|}
\hline & 1 & 2 & 3 & 4 & 5 & 6 & 7 & 8 & 9 & 10 & 11 & 12 & 13 \\
\hline $\mathrm{SIO}_{2}$ & 48.9 & 48.0 & 39.4 & 53.5 & 55.8 & 49.9 & 49.8 & 46.8 & 47.2 & 49.74 & 58.5 & 53.3 & 55.8 \\
\hline $\mathrm{N}_{2} \mathrm{O}_{3}$ & 11.0 & 12.5 & 1.8 & 13.0 & 13.5 & 13.6 & 13.6 & 12.5 & 13.4 & 14.8 & 15.1 & 15.5 & 14.4 \\
\hline $\mathrm{Fe}_{2} \mathrm{O}_{3}$ & 4.7 & 4.3 & 3.2 & 3.0 & 4.8 & 3.8 & 3.9 & 4.4 & 3.5 & 5.0 & 4.9 & 4.2 & 0.8 \\
\hline $\mathrm{FoO}$ & 15.5 & 14.0 & 4.9 & 8.3 & 12.0 & 8.5 & 9.2 & 11.8 & 11.2 & 9.0 & 7.8 & 8.4 & 11.9 \\
\hline $\mathrm{MgO}$ & 6.5 & 6.4 & 33.9 & 5.2 & 3.7 & 6.8 & 5.6 & 5.5 & 5.6 & 6.3 & 3.4 & 3.2 & 3.2 \\
\hline MnO & 0.28 & 0.30 & 0.13 & 0.19 & 0.25 & 0.20 & 0.20 & 0.27 & 0.23 & 0.24 & 0.22 & 0.22 & 0.22 \\
\hline $\mathrm{CaO}$ & 9.8 & 9.5 & 7.2 & 11.2 & 6.9 & 12.5 & 12.8 & 10.8 & 11.5 & 10.5 & 9.6 & 9.5 & 8.4 \\
\hline $\mathrm{Na}_{2} \mathrm{O}$ & 1.0 & 1.3 & 0.7 & 1.8 & 1.6 & 1.5 & 1.2 & 1.6 & 1.8 & 1.7 & 2.0 & 20 & 2.1 \\
\hline $\mathrm{K}_{2} \mathrm{O}$ & 0.6 & 0.2 & 0.1 & 0.6 & 1.2 & 0.5 & 0.5 & 0.8 & 0.5 & 0.5 & 1.2 & 1.3 & 1.4 \\
\hline $\mathrm{TiO}_{2}$ & 2.5 & 2.3 & 0.3 & 1.1 & 2.2 & 1.6 & 1.7 & 3.5 & 3.5 & 2.1 & 1.6 & 1.6 & 1.3 \\
\hline $\mathrm{P}_{2} \mathrm{O}_{5}$ & 0.20 & 0.20 & 0.15 & 0.12 & 0.25 & 0.26 & 0.26 & 0.56 & 0.56 & 0.24 & 0.23 & 0.23 & 0.15 \\
\hline Sum & 99.5 & 99.5 & 92.9 & 99.1 & 99.8 & 99.2 & 88.9 & 99.4 & 99.0 & 99.8 & 9.5 & 99.5 & 99.7 \\
\hline v & 280 & 280 & 0 & 150 & 230 & 180 & 190 & 320 & 330 & 230 & 210 & 190 & 200 \\
\hline a & 150 & 150 & 2030 & 100 & 70 & 270 & 210 & 140 & 140 & 150 & $\infty$ & 50 & 50 \\
\hline Co & 37 & 37 & 66 & 48 & 41 & 35 & 40 & 13 & $\theta$ & 30 & 35 & 47 & 35 \\
\hline $\mathrm{Ni}$ & 170 & 290 & 170 & 230 & 200 & 220 & 230 & $\infty$ & 50 & 70 & 170 & 150 & 140 \\
\hline $\mathrm{Cu}$ & 130 & 100 & 70 & 70 & 70 & 100 & 100 & 120 & 120 & 80 & 130 & 110 & 120 \\
\hline $\mathrm{Zn}$ & 120 & 130 & 70 & 80 & 130 & 80 & 80 & 140 & 110 & 100 & 90 & $\mathbf{\infty}$ & $\infty$ \\
\hline$R b$ & 16 & 22 & 0 & 13 & 42 & 5 & $\theta$ & 19 & 13 & 13 & 18 & 21 & 33 \\
\hline Sr & 110 & 100 & 50 & 100 & 370 & 220 & 2200 & 520 & 770 & 380 & 270 & 270 & 190 \\
\hline$Y$ & 39 & 39 & 25 & 31 & 27 & 26 & 26 & 21 & 18 & 25 & 28 & 20 & 32 \\
\hline $\mathrm{Zr}$ & 160 & 150 & 90 & 160 & 200 & 150 & 160 & 240 & 250 & 190 & 160 & 200 & 170 \\
\hline $\mathrm{Nb}$ & 22 & 25 & 0 & 70 & 43 & 6 & 13 & 52 & 50 & 31 & 8 & 12 & 8 \\
\hline $\mathrm{Ba}$ & 140 & 140 & 200 & 200 & 420 & 280 & 240 & 540 & 470 & 320 & 410 & 370 & 330 \\
\hline
\end{tabular}




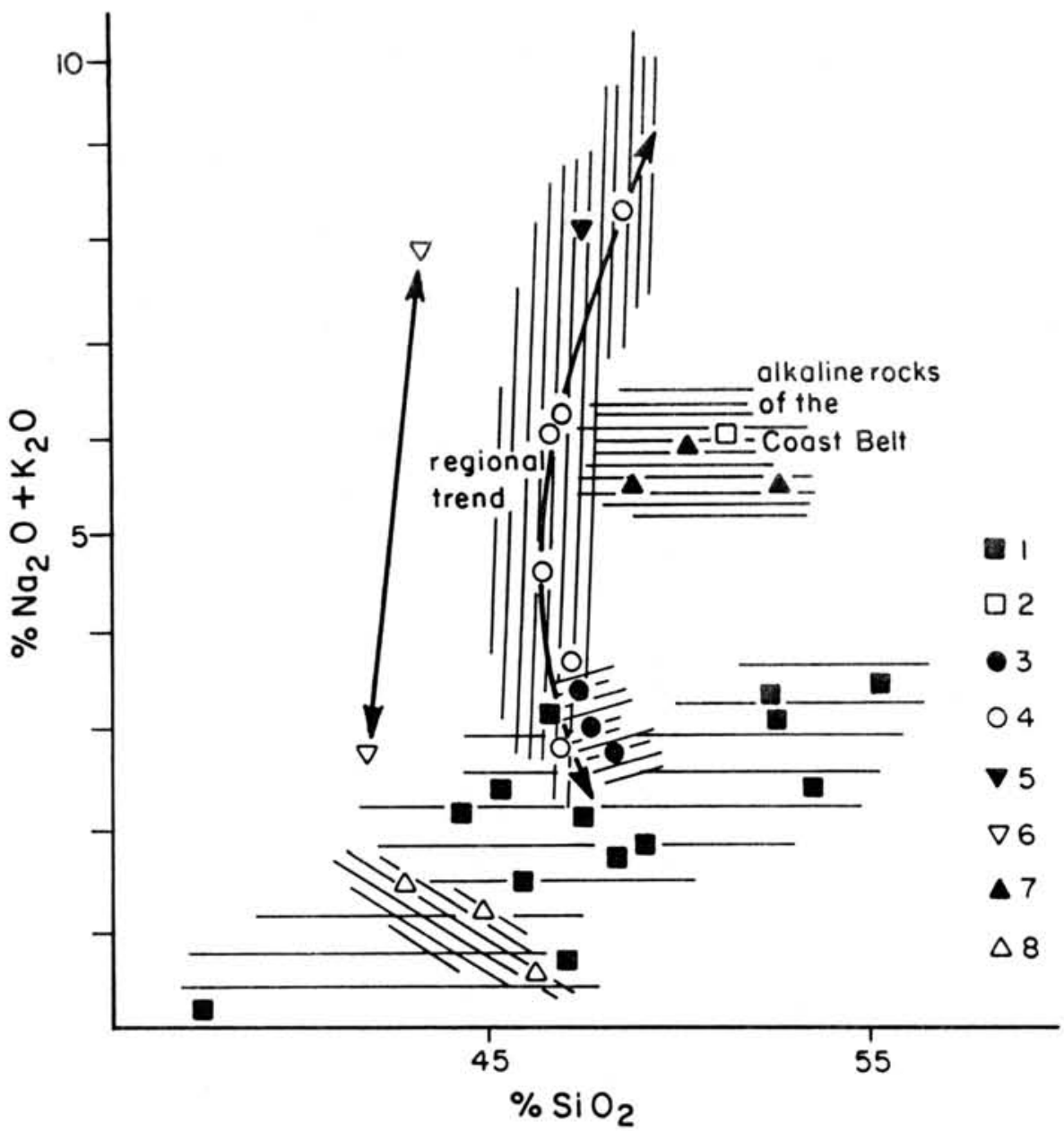

Figure $2-\mathrm{SiO}_{2}$-Alkalies-diagram: Relation between the samples of Figure 2 and other basic rock groups. 1. Studied samples; 2. Basic dike of the Paraíba do Sul Complex; 3 - Dikes of the Sabinópolis-Virginopolis area (includes data of OLIVEIRA et al., 1984); 4. Means of samples from the Espinhaço range (after BIONDI et al., 1987); 5. Dikes of the Conceiçăo de Muqui area; 6. Means of samples from Mimoso do Sul (WIEDEMANN et al., 1986); 7. Compositions of the Santa Angélica and the Castelo Intrusions; 8 . Composition of the Venda Nova body. The patterned areas show the fields defined for each group of analyses. 


\section{REFERENCES}

BIONDI, J.C.; SCHRANK, A.; FREITAS PINHEIRO, J.C. (1978) Basitos $\theta$ ultrabasitos do Espinhaço Meridional e região sul de Minas Gerais. In: CONGRESSO BRASILEIRO DE GEOLOGIA, 30., Recife, 1978. Anais. Recife, SBG. V.3, p.1213-1225.

CORREIA NEVES, J.M. \& HORN, H.A. (1988) Petrologie und Geochemie der basischen Gesteine der Region Centro-Norte der Provinz Mantiqueira (Brasilien). In: LATEINAMERIKA-KOLLOQUIUM, Hannover, 1988. V.1, p.13.

HORN, H.A. (1986) Plutonite in Espirito Santo: geochemische untersuchungen an intrusivkomplexen des Brasiliano im Kuestenguertel von Espirito Santo/Brasilien. Munich, 308p. (PhD. These-Institute of Geology/LMU).

OLIVEIRA, E.P.; FONSECA, E.G.; MARQUES, N.M.G. (1984) Petrografia e geoquímica de uma sulte de diques máficos transamazônicos da região de Virginópolis, Minas Gerais. In: CONGRESSO BRASILEIRO DE GEOLOGIA, 33., Rio de Janeiro, 1984. Anais. Rio de Janeiro, SBG. V.9, p.41554165.

WIEDEMANN, C.M.; BAYER, P.; HORN, H.A.; LAMMERER, B.; LUDKA, I.P.; SCHMIDT-THOME, R.; DIEFENBACH, K.W. (1986) Maciços intrusivos do Sul do Espírito Santo e seu contexto regional. Revista Brasileira de Geociências, 16(1):24-37. 